\title{
Karakteristik Kimia dan Organoleptik Biskuit dengan Penambahan Tepung Kacang Kedelai (Glycine max) dan Tepung Kulit Buah Naga Merah (Hylocereus costaricensis)
}

\author{
Dian Puspita1*, Noor Harini ${ }^{2}$, Sri Winarsih ${ }^{3}$ \\ ${ }^{1}$ Prodi Teknologi Pangan, Fakultas Pertanian Peternakan, Universitas Muhammadiyah Malang, \\ Malang, Indonesia \\ *Corresponding author email: dhiandian02@gmail.com
}

\begin{abstract}
Indonesia is a country that has a high level of biscuit consumption. This is supported by many local food commodities. Therefore, many food products have emerged that use local food ingredients, such as bread, biscuits and cakes. One effort that can be made to enrich the nutritional content of biscuits is to add soybean flour which is rich in protein and flour of red dragon fruit peel which is rich in dietary fiber. The purpose of this study was to determine the effect of the ratio of wheat flour, soybean flour and red dragon fruit peel flour to chemical and organoleptic quality of biscuits. This research used a simple randomized block design with ratio of wheat flour, soybean flour, and red dragon fruit peel flour consisting of 10 levels: PO (100\%:0\%:0\%), P1 (80\%:10\%:10\%), P2 (70\%:20\%:10\%), P3 (60\%:30\%:10\%), P4 (75\%:10\%:15\%), P5 (65\%:20\%:15\%), P6 (55\%:30\%:15\%), P7 (70\%:10\%:20\%), P8 (60\%:20\%:20\%), P9 (50\%:30\%:20\%). Each level is repeated 2 times. The parameters being observed were level of protein, fat, crude fiber, water, ash, and organoleptics (aroma, taste and texture). The results showed that the proportion of wheat flour, soybean flour and red dragon fruit peel flour had a very significant effect on level of water, protein, crude fiber, and organoleptic (taste, aroma, and texture). Treatment of biscuits with proportion of wheat flour 60\%: 30\% soybean flour: $10 \%$ red dragon fruit peel flour was the best treatment with level of water 6,58\%, ash $0,76 \%$, fat $27,95 \%$, protein $9,74 \%$, crude fiber $6,10 \%$, organoleptic of taste 4,65 (delicious), aroma (rather tasty), and texture (rather not hard)

Keywords: biscuits, red dragon fruit peel, soybeans
\end{abstract}

\section{PENDAHULUAN}

Makanan ringan merupakan makanan favorit masyarakat yang mudah dibawa dan praktis. Biskuit merupakan salah satu contoh makanan ringan yang digemari semua kalangan usia dari anak-anak hingga dewasa. Biskuit yang beredar di pasaran umumnya terbuat dari beberapa bahan pangan utama yaitu tepung terigu, margarin serta bahan pengembang. Biskuit yang beredar nyatanya masih memiliki kandungan protein dan serat yang rendah. Hal ini sesuai dari pernyataan Ningrum (2017) bahwa biskuit komersial yang telah beredar di pasaran mengandung protein yang cukup rendah yaitu $9 \%$. Selain itu, 
maraknya kasus stunting yang terjadi pada balita di Indonesia terjadi karena kurangnya asupan protein yang cukup sehingga mengakibatkan pertumbuhan balita yang tidak maksimal.

Salah satu hal yang dapat dilakukan untuk mengurangi kasus stunting adalah memanfaatkan biskuit yang diperkaya kandungan protein. Kedelai adalah salah satu bahan pangan yang mengandung protein tinggi. Hal ini sesuai Balitkabi (2016) yang menyatakan bahwa tepung kedelai varietas Anjasmoro memiliki protein 41,8\%. Kandungan protein tersebut lebih tinggi dibandingkan protein kedelai impor sebesar 28,62\% (Yudiono, 2020). Biskuit juga dapat ditambah serat pangan dengan memanfaatkan limbah kulit buah naga merah. Menurut Saneto (2012) serat pangan yang terkandung dalam kulit buah naga merah adalah 46,7\% lebih tinggi dibandingkan buah persik dan pear. Oleh karena itu diharapkan penambahan kedelai dan kulit buah naga merah dengan mengolahnya menjadi tepung sebagai bahan baku dapat meningkatkan kualitas biskuit.

Penelitian mengenai biskuit dengan penambahan tepung kedelai telah dilakukan Puspita (2015) bahwa biskuit berbasis tepung sukun yang ditambah tepung kedelai 15\% mengandung protein 9,47\%. Penelitian Aini (2013) juga meneliti biskuit berbasis tepung garut dan ubi jalar yang disubstitusi tepung kedelai 25\% mengandung protein hingga 10,02\%. Selain itu penelitian dengan penambahan kulit buah naga merah telah diteliti oleh Lianawati dan Heri (2019) bahwa pancake yang disubstitusi tepung kulit buah naga merah 50\% menghasilkan kadar serat sebanyak 3,72 gram/100gram. Kemudian Rochmawati (2019) juga menyatakan cookies yang ditambah tepung kulit buah naga merah 90\% menghasilkan kadar serat sebesar 31,26\%.

Berdasarkan penelitian yang dilakukan sebelumnya, maka penelitian ini ingin menambah tepung kacang kedelai dan tepung kulit buah naga merah sebagai bahan baku dengan harapan dapat meningkatkan kadar protein dan serat pangan yang ada pada biskuit. Penelitian ini bertujuan untuk mengetahui pengaruh proporsi proporsi tepung terigu, tepung kedelai, dan tepung kulit buah naga merah terhadap kualitas kimia dan organoleptik biskuit.

\section{METODE PENELITIAN}

\section{Alat dan Bahan}

Alat yang digunakan meliputi timbangan analitik merek Pioner ohaus, panci, ayakan merek Retsch, blender merek Kirin, pisau, mixer merek Sharp, cetakan biskuit, loyang, thermometer merek Alpha, cabinet dryer merek Wanedi, oven merek Romand, oven roti merek Fomac, gelas beaker, labu Kjedahl, corong, spatula, pipet tetes, hot plate merek Maspion, pendingin balik, corong buncher, tanur, lemari asam, gelas ukur, erlenmeyer, buret, mortal martil, tabung 
destilasi, kertas saring whatman, soxhlet, labu lemak, desikator, water bath, aluminium foil, dan cawan porselen.

Bahan baku yang digunakan meliputi kacang kedelai varietas Anjasmoro dan kulit buah naga merah yang didapat dari Pasar Bunulrejo, Malang, tepung terigu Kunci Biru, tepung maizena, gula, margarin, garam, telur, baking powder, dan vanili. Bahan analisis yang digunakan yaitu katalisator ( $\mathrm{Na}_{2} \mathrm{SO}_{4}, \mathrm{HgO}$ ), $\mathrm{H}_{2} \mathrm{SO}_{4}$ pekat, $\mathrm{H}_{2} \mathrm{SO}_{4} 0,325 \mathrm{~N}$, aquades, $\mathrm{NaOH} 50 \%, \mathrm{NaOH} 1,25 \mathrm{~N}$, etanol, asam borat, $\mathrm{HCl} 0,02 \mathrm{~N}$, anti buih dan petroleum benzene.

\section{Rancangan Penelitian dan Analisa Data}

Rancangan penelitian ini menggunakan percobaan (eksperimen) Rancangan Acak Kelompok (RAK) secara sederhana. Perlakuan yang dilakukan adalah formulasi biskuit dari proporsi tepung terigu, tepung kedelai, dan tepung kulit buah naga merah yang terdiri dari 10 level masing-masing P0 (100\%:0\%:0\%), P1 (80\%:10\%:10\%), P2 (70\%:20\%:10\%), P3 (60\%:30\%:10\%), P4 (75\%:10\%:15\%), P5 (65\%:20\%:15\%), P6 (55\%:30\%:15\%), P7 (70\%:10\%:20\%), P8(60\%:20\%:20\%), dan P9(50\%:30\%:20\%). Setiap level diperlakukan sebanyak 2 kali ulangan. Data yang didapat dianalisa menggunakan uji statistik atau ANOVA (Analysis of Variance) untuk mengetahui perlakuan tersebut memberikan pengaruh nyata terhadap sifat kimia dan organoleptik pada formula biskuit dan dilanjutkan dengan uji DMRT (Duncan's Multiple Range Test). Uji perlakuan terbaik menggunakan metode De Garmo.

\section{Pembuatan Tepung Kedelai}

Pembuatan tepung kedelai melalui proses sortasi kacang kedelai terlebih dahulu lalu dibilas dan direndam dengai air selama 9 jam. Kemudian dilakukan pemisahan biji kacang kedelai dengan kulit arinya dan direbus selama 10 menit. Setelah itu kedelai ditiriskan dan dikeringkan di bawah sinar matahari selama 24 jam. Kacang kedelai yang sudah kering dihancurkan menggunakan blender dan dihaluskan dengan ayakan 80 mesh.

\section{Pembuatan Tepung Kulit Buah Naga Merah}

Buah naga merah disortasi terlebih dahulu dan dikupas agar kulit dan daging buah terpisah. Kulit buah naga diblansing menggunakan metode hot water blanching selama dua menit dengan suhu $80^{\circ} \mathrm{C}$. Setelah itu, kulit dipotong-potong menjadi lebih kecil dan dimasukkan ke dalam cabinet dryer dengan suhu $60^{\circ} \mathrm{C}$ selama 20 jam untuk dihilangkan kadar airnya. Kulit yang sudah kering dihancurkan di dalam blender dan diayak dengan ayakan 40 mesh.

\section{Pembuatan Biskuit}

Bahan-bahan yang disiapkan terlebih dahulu ditimbang sesuai dengan takaran yaitu tepung terigu 100 g, tepung kacang kedelai, tepung kulit buah naga merah, $40 \mathrm{~g}$ gula, $50 \mathrm{~g}$ margarin, $15 \mathrm{~g}$ kuning telur, $1 \mathrm{~g}$ garam, $5 \mathrm{~g}$ tepung maezena, 0,5 g baking powder, dan 0,5 vanili. Pencampuran pertama dengan 
memasukkan margarin dan kuning telur lalu ditambah gula dan garam yang dimixing selama 5 menit. Selanjutnya dimasukkan tepung terigu, tepung kedelai, tepung kulit buah naga, tepung maizena, vanili dan baking powder dimixing lagi selama 10 menit. Setelah menjadi adonan yang menyatu, biskuit dicetak berbentuk lingkaran dengan berat masing-masing 5-8 gram per keping dan diletakkan di atas loyang. Biskuit dimasukkan ke dalam oven dan dipanggang dengan suhu $150^{\circ} \mathrm{C}$ selama 20 menit. Biskuit didinginkan dan dikemas dalam toples yang tertutup rapat.

\section{Parameter Penelitian}

Parameter penelitian yang dilakukan terdiri dari beberapa analisa yaitu analisa kadar air, abu, lemak, protein, serat kasar, dan organoleptik (rasa, aroma, dan tekstur).

\section{HASIL DAN PEMBAHASAN \\ Kadar Air}

Berdasarkan hasil analisis ragam membuktikan bahwa formulasi biskuit dengan perbandingan tepung terigu, tepung kedelai dan tepung kulit buah naga merah berpengaruh terhadap kadar air biskuit. Perolehan data kadar air ditampilkan dalam Tabel 1.

Tabel 1. Rerata Kadar Air Produk Biskuit Formulasi Tepung Terigu, Kedelai, dan Kulit Buah Naga Merah

\begin{tabular}{cc}
\hline $\begin{array}{c}\text { Formulasi Tepung } \\
\text { Terigu(\%): Kedelai(\%): Kulit Buah Naga Merah(\%) }\end{array}$ & Kadar Air (\%) \\
\hline P0 $(100: 0: 0)$ & $4,64^{\mathrm{a}}$ \\
P1 $(80: 10: 10)$ & $5,49^{\mathrm{ab}}$ \\
P2 $(70: 20: 10)$ & $5,94^{\mathrm{ab}}$ \\
P3 $(60: 30: 10)$ & $6,58^{\mathrm{bc}}$ \\
P4 $(75: 10: 15)$ & $7,57^{\mathrm{cd}}$ \\
P5 $(65: 20: 15)$ & $7,61^{\mathrm{cd}}$ \\
P6 $(55: 30: 15)$ & $8,37^{\mathrm{de}}$ \\
P7 $(70: 10: 20)$ & $9,55^{\mathrm{ef}}$ \\
P8 $(60: 20: 20)$ & $10,34^{\mathrm{f}}$ \\
P9 $(50: 30: 20)$ & $8,85^{\mathrm{de}}$ \\
\hline
\end{tabular}

Keterangan: Notasi yang ditulis dengan huruf berbeda menunjukkan ada perbedaan antar perlakuan berbeda nyata pada uji Duncan (DMRT) $5 \%$.

Berdasarkan Tabel 1 diketahui bahwa rata-rata nilai kadar air yang diperoleh berkisar 4,64\%-10,34\%. Hasil kadar air pada perlakuan P1-P9 ini tidak memenuhi standar mutu SNI 973:2011 karena kadar air yang dihasilkan lebih dari 5\%. Menurut SNI 3751:2009, kadar air yang dimiliki tepung terigu maksimal 14,5\% kemudian menurut penelitian Sarofatin (2018) kadar air tepung kulit buah naga merah adalah 13,17\% dan menurut Jannah (2020) kadar air pada tepung kedelai yaitu $11,11 \%$. 
Perbedaan jumlah tepung kedelai yang ditambahkan pada biskuit jika semakin tinggi maka kadar air semakin meningkat. Lestari (2018) menyatakan pada protein yang tinggi terdapat gugus karboksil yang memiliki daya serap air tinggi sehingga air dalam bahan dapat diserap oleh gugus karboksil. Penelitian ini diperkuat oleh Lestari (2018) bahwa kadar air cookies substitusi tepung kacang kedelai $25 \%$ adalah $3,60 \%$.

Tepung kulit buah naga merah yang ditambahkan juga meningkatkan kadar air karena mengandung serat yang dapat mengikat air. Penelitian Saneto (2012) menyatakan kulit buah naga merah mengandung serat 46,7\%. Hal ini diperkuat Lestari (2018) bahwa serat pada bahan pangan dapat mengikat air walaupun bahan tersebut dipanaskan. Kandungan air yang berkurang sedikit sehingga di dalam bahan masih ada air yang tertinggal.

\section{Kadar Abu}

Berdasarkan hasil analisis ragam membuktikan bahwa formulasi biskuit dengan perbandingan tepung terigu, tepung kedelai dan tepung kulit buah naga merah tidak berpengaruh terhadap kadar abu biskuit. Perolehan data kadar abu ditampilkan dalam Gambar 1.

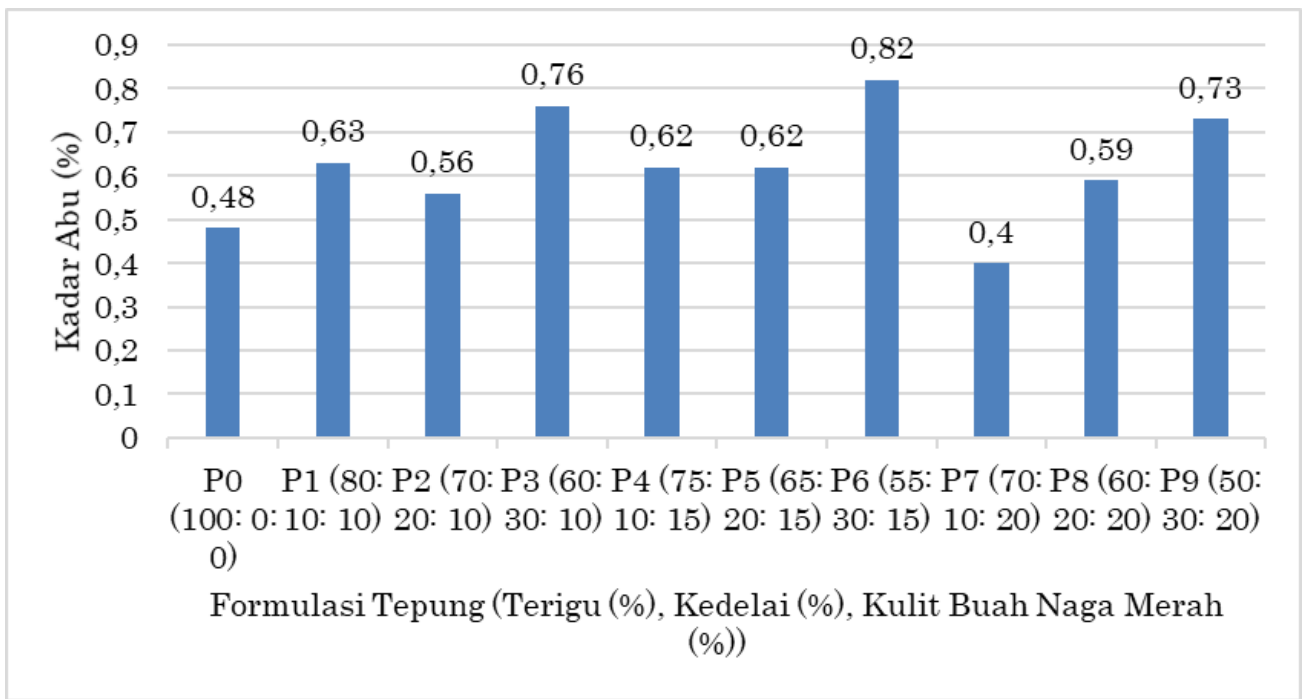

Gambar 1. Histogram Rerata Kadar Abu Biskuit Formulasi Tepung Terigu, Kedelai, dan Kulit Buah Naga Merah

Berdasarkan Gambar 1 diketahui bahwa rata-rata nilai kadar abu yang diperoleh berkisar 0,40\%-0,82\%. Hasil kadar abu tersebut memenuhi standar SNI 01 2973:2011 dengan maksimal 3,5\%. Peningkatan kadar abu yang tidak signifikan diiringi dengan tepung kedelai yang ditambahkan. Jannah (2020) menyatakan tepung kedelai mengandung kadar abu sebesar 2,99\% dibandingkan tepung terigu $0,46 \%$. 
Tepung kulit buah naga merah yang ditambahkan juga tidak mempengaruhi kadar abu biskuit. Simangungsong (2014) menyatakan kulit buah naga merah memilki kadar abu 2,60\% lebih tinggi dari tepung terigu hanya $0,25-0,60 \%$. Penambahan tepung kulit buah naga merah tidak terlalu banyak sehingga tidak mempengaruhi kadar abu biskuit walaupun mineral yang ada di dalam kulit buah naga merah lebih tinggi. Mineral paling banyak yang terkandung di kulit buah naga adalah kalsium dan fosfor.

\section{Kadar Lemak}

Berdasarkan hasil analisis ragam membuktikan bahwa formulasi biskuit dengan perbandingan tepung terigu, tepung kedelai dan tepung kulit buah naga merah tidak berpengaruh terhadap kadar lemak biskuit. Perolehan data kadar lemak ditampilkan dalam Gambar 2.

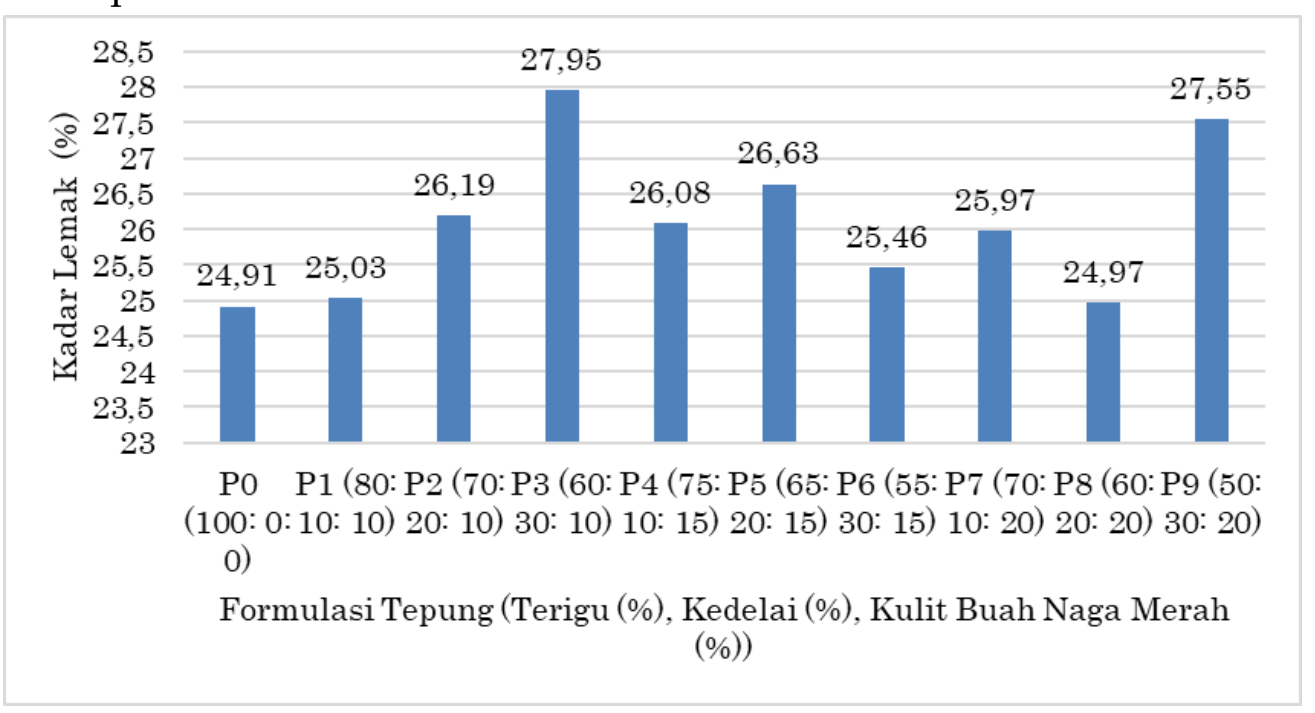

Gambar 2. Histogram Rerata Kadar Abu Biskuit Formulasi Tepung Terigu,

Kedelai, dan Kulit Buah Naga Merah

Peningkatan kadar lemak pada biskuit tidak signifikan yang diiringi dengan penambahan tepung kedelai. Balitkabi (2016) menyatakan kadar lemak tepung kedelai adalah $17,2 \%$ lebih tinggi dibandingkan tepung terigu hanya 1,3\% (Direktorat Gizi, 2018). Hal ini tidak sesuai dengan penelitian Thomas (2017) bahwa biskuit berbahan baku tepung pisang goroho dengan ditambah tepung kedelai menghasilkan kadar lemak 8,80\% - 15,29\%. Perbedaan ini karena penambahan tepung kedelai yang berbeda di masing-masing perlakuan dan kadar lemak tepung pisang goroho 0,97\% lebih rendah dibanding tepung terigu.

Tepung kulit buah naga merah yang ditambahkan tidak mempengaruhi kadar lemak biskuit secara signifikan. Simangunsong (2014) menyatakan tepung kulit buah naga merah memiliki kadar lemak 2,60\%. Hasil dari penelitian ini 
sesuai dengan Rochmawati (2019) bahwa cookies berbasis tepung kulit buah naga merah mengandung kadar lemak antara $21,09 \%-25,45 \%$.

\section{Kadar Protein}

Berdasarkan hasil analisis ragam membuktikan bahwa formulasi biskuit dengan perbandingan tepung terigu, tepung kedelai dan tepung kulit buah naga merah berpengaruh terhadap kadar protein biskuit. Perolehan data kadar protein ditampilkan dalam Tabel 2.

Tabel 2. Rerata Kadar Protein Produk Biskuit Formulasi Tepung Terigu, Kedelai, dan Kulit Buah Naga Merah

\begin{tabular}{cc}
\hline Formulasi Tepung & Kadar Protein (\%) \\
\hline Terigu(\%): Kedelai(\%): Kulit Buah Naga Merah(\%) & $6,45^{\mathrm{a}}$ \\
P0 $(100: 0: 0)$ & $8,51^{\mathrm{b}}$ \\
P1 $(80: 10: 10)$ & $9,24^{\mathrm{bc}}$ \\
P2 $(70: 20: 10)$ & $9,74^{\mathrm{bc}}$ \\
P3 $(60: 30: 10)$ & $8,92^{\mathrm{bc}}$ \\
P4 $(75: 10: 15)$ & $10,41^{\mathrm{cd}}$ \\
P5 $(65: 20: 15)$ & $10,89^{\mathrm{de}}$ \\
P6 $(55: 30: 15)$ & $8,17^{\mathrm{b}}$ \\
P7 $(70: 10: 20)$ & $8,59^{\mathrm{b}}$ \\
P8 $(60: 20: 20)$ & $10,99^{\mathrm{e}}$ \\
\hline
\end{tabular}

Keterangan: Notasi yang ditulis dengan huruf berbeda menunjukkan ada perbedaan antar perlakuan berbeda nyata pada uji Duncan (DMRT) $5 \%$.

Berdasarkan Tabel 2 diketahui bahwa nilai kadar protein yang diperoleh berkisar 6,45-10,99\%. Hasil kadar protein tersebut memenuhi standar SNI 012973:2011 yaitu diatas 5\%. Kadar protein dari penelitian ini meningkat seiring tepung kedelai yang ditambahkan. Menurut Fajiarningsih (2013) penggunaan tepung terigu (soft wheat) sebagai bahan baku cookies mengandung protein sebesar 8-9\%. Balitkabi (2016) menyatakan tepung kedelai varietas Anjasmoro mengandung protein cukup tinggi yaitu $41,8 \%$. Hasil penelitian ini sesuai dengan Lestari (2018) bahwa cookies berbasis tepung ganyong dan tepung kacang kedelai (55:25) memiliki kadar protein sebesar 18,91\%.

Tepung kulit buah naga merah yang ditambahkan mempengaruhi kadar protein biskuit namun tidak terlalu banyak. Proporsi tepung kulit buah naga merah yang ditambahan hanya 10-20 g. Hasil ini diperkuat oleh pernyataan dari Rochmawati (2019) bahwa kadar protein cookies yang ditambahkan tepung kulit buah naga merah adalah 5,63\% kemudian Saneto (2012) juga menyatakan bahwa tepung kulit buah naga mengandung protein yang cukup rendah yaitu $3,2 \%$. 


\section{Kadar Serat}

Berdasarkan hasil analisis ragam membuktikan bahwa formulasi biskuit dengan perbandingan tepung terigu, tepung kedelai dan tepung kulit buah naga merah berpengaruh terhadap kadar serat biskuit. Perolehan data kadar serat ditampilkan dalam Tabel 3.

Berdasarkan Tabel 3 diketahui bahwa nilai kadar serat yang diperoleh berkisar 1,06-10,35\%. BPOM (2016) menyatakan produk pangan disebut sumber serat jika mememiliki serat $3 \mathrm{~g} / 100 \mathrm{~g}$ dan dikatakan tinggi serat jika memiliki serat $6 \mathrm{~g} / 100 \mathrm{~g}$. Berdasarkan pernyataan tersebut, kadar serat penelitian ini dapat disebut sumber serat dan tinggi serat kecuali perlakuan P0 tanpa penambahan tepung kedelai dan tepung kulit buah naga merah tidak sesuai standar BPOM karena kadar serat yang terkandung hanya 1,06\%.

Tabel 3. Rerata Kadar Serat Produk Biskuit Formulasi Tepung Terigu, Kedelai, dan Kulit Buah Naga Merah

\begin{tabular}{cc}
\hline $\begin{array}{c}\text { Formulasi Tepung } \\
\text { Terigu(\%): Kedelai(\%): Kulit Buah Naga Merah(\%) }\end{array}$ & Kadar Serat (\%) \\
\hline P0 $(100: 0: 0)$ & $1,06^{\mathrm{a}}$ \\
P1 $(80: 10: 10)$ & $5,46^{\mathrm{c}}$ \\
P2 $(70: 20: 10)$ & $3,53^{\mathrm{b}}$ \\
P3 $(60: 30: 10)$ & $6,10^{\mathrm{c}}$ \\
P4 $(75: 10: 15)$ & $8,56^{\mathrm{d}}$ \\
P5 $(65: 20: 15)$ & $9,32^{\mathrm{de}}$ \\
P6 $(55: 30: 15)$ & $9,73^{\mathrm{de}}$ \\
P7 $(70: 10: 20)$ & $10,32^{\mathrm{e}}$ \\
P8 $(60: 20: 20)$ & $10,35^{\mathrm{e}}$ \\
P9 $(50: 30: 20)$ & $10,04^{\mathrm{e}}$ \\
\hline
\end{tabular}

Keterangan: Notasi yang ditulis dengan huruf berbeda menunjukkan ada perbedaan antar perlakuan berbeda nyata pada uji Duncan (DMRT) $5 \%$.

Kadar serat dari penelitian ini meningkat seiring penambahan tepung kulit buah naga merah dan tepung kedelai. Hal ini dipengaruhi oleh kandungan serat tinggi pada kulit buah naga merah sehingga mempengaruhi kadar serat kasar biskuit menjadi tinggi. Menurut hasil penelitian dari Saneto (2012) kadar serat pangan yang terkandung dari kulit buah naga merah adalah 46,7\%. Kandungan serat ini lebih tinggi dibanding serat tepung terigu sebesar 5,12\% (Utama, 2019). Selain itu, peningkatan kadar serat biskuit dipengaruhi oleh penambahan tepung kedelai meskipun Cahyani (2020) menyatakan serat tepung kedelai hanya $3,2 \%$.

\section{Hasil Analisa Organoleptik \\ Rasa}

Berdasarkan hasil analisis ragam membuktikan bahwa formulasi biskuit dengan perbandingan tepung terigu, tepung kedelai dan tepung kulit buah naga 
merah berpengaruh terhadap organoleptik rasa biskuit. Perolehan data organoleptik rasa ditampilkan dalam Tabel 4.

Tabel 4. Rerata Organoleptik Rasa Biskuit Produk Biskuit Formulasi Tepung Terigu, Kedelai, dan Kulit Buah Naga Merah

\section{Formulasi Tepung}

Terigu(\%): Kedelai(\%): Kulit Buah Naga Merah(\%)

$\begin{array}{ll}\text { P0 }(100: 0: 0) & 6,20^{\mathrm{h}} \\ \text { P1 }(80: 10: 10) & 4,95^{\mathrm{g}} \\ \text { P2 }(70: 20: 10) & 4,80^{\mathrm{fg}} \\ \text { P3 }(60: 30: 10) & 4,65^{\mathrm{f}} \\ \text { P4 }(75: 10: 15) & 4,65^{\mathrm{ef}} \\ \text { P5 }(65: 20: 15) & 4,20^{\mathrm{de}} \\ \text { P6 }(55: 30: 15) & 4,05^{\mathrm{d}} \\ \text { P7 }(70: 10: 20) & 3,70^{\mathrm{c}} \\ \text { P8 }(60: 20: 20) & 3,10^{\mathrm{a}} \\ \text { P9 }(50: 30: 20) & 3,40^{\mathrm{b}}\end{array}$

Keterangan: Notasi yang ditulis dengan huruf berbeda menunjukkan ada perbedaan antar perlakuan berbeda nyata pada uji Duncan (DMRT) $5 \%$.

Keterangan skor: (1) sangat tidak enak, (2) tidak enak, (3) agak tidak enak, (4) netral, (5) agak enak, (6) enak, (7) sangat enak

Berdasarkan Tabel 4 diketahui bahwa rerata hedonik rasa yang diperoleh dari penilaian panelis berkisar 3,10-6,20. Formulasi biskuit ini memiliki rasa khas manis dari tepung kedelai dan tepung kulit buah naga merah. Biskuit yang disukai panelis adalah biskuit tanpa penambahan tepung kedelai dan tepung kulit buah naga merah karena gurih dan tidak ada rasa langu ataupun pahit. Noor (2016) menyatakan kulit buah naga merah terdapat senyawa tanin yang memberikan rasa pahit. Hal ini diperkuat oleh Triwulandari (2018) bahwa rasa yang dihasilkan dari cookies berbasis tepung kulit buah naga merah sebanyak 6\% adalah kurang enak dan pahit.

Tepung kedelai yang ditambahkan semakin banyak juga mempengaruhi rasa pada biskuit menjadi lebih langu. Menurut Jannah (2020) pada kedelai terdapat senyawa glikosida (soyasaponin dan sapogenol) yang menyebabkan rasa pahit pada kedelai. Hal ini diperkuat bahwa cookies yang ditambahkan tepung kulit ari kedelai 40\%, panelis memberi nilai organoleptik rasa yang agak tidak enak.

Aroma

Berdasarkan hasil analisis ragam membuktikan bahwa formulasi biskuit dengan perbandingan tepung terigu, tepung kedelai dan tepung kulit buah naga merah berpengaruh terhadap organoleptik aroma biskuit. Perolehan data organoleptik aroma ditampilkan dalam Tabel 5. 
Tabel 5. Rerata Organoleptik Aroma Produk Biskuit Formulasi Tepung Terigu, Kedelai, dan Kulit Buah Naga Merah

\begin{tabular}{cc}
\hline Formulasi Tepung & Hedonik Aroma \\
\hline Terigu(\%): Kedelai(\%): Kulit Buah Naga Merah(\%) & $6,00^{\mathrm{f}}$ \\
P0 $(100: 0: 0)$ & $5,60^{\mathrm{e}}$ \\
P1 $(80: 10: 10)$ & $5,00^{\mathrm{d}}$ \\
P2 $(70: 20: 10)$ & $4,95^{\mathrm{d}}$ \\
P3 $(60: 30: 10)$ & $4,55^{\mathrm{b}}$ \\
P4 $(75: 10: 15)$ & $4,20^{\mathrm{a}}$ \\
P5 $(65: 20: 15)$ & $4,10^{\mathrm{a}}$ \\
P6 $(55: 30: 15)$ & $4,75^{\mathrm{c}}$ \\
P7 $(70: 10: 20)$ & $4,15^{\mathrm{a}}$ \\
P8 $(60: 20: 20)$ & $4,45^{\mathrm{b}}$ \\
\hline
\end{tabular}

Keterangan: Notasi yang ditulis dengan huruf berbeda menunjukkan ada perbedaan antar perlakuan berbeda nyata pada uji Duncan (DMRT) $5 \%$.

Keterangan skor: (1) sangat tidak sedap, (2) tidak sedap, (3) agak tidak sedap, (4) netral, (5) agak sedap, (6) sedap, (7) sangat sedap

Berdasarkan Tabel 5 diketaui bahwa rerata hedonik aroma yang diperoleh dari penilaian panelis berkisar 4,10-6,00. Rerata aroma biskuit yang disukai panelis semakin menurun seiring dengan tepung kulit buah naga merah yang ditambahkan. Penggunaan tepung kulit buah naga pada formulasi biskuit membuat aroma kulit buah naga merah yang khas pada biskuit menjadi kuat. $\mathrm{Wu}$ (2006) menyatakan pada kulit buah naga merah terdapat senyawa yang memperkuat aroma alami yaitu polifenol, alkaloid, terpenoid, flavonoid, tiamin, niasin, piridoksin, kabolamin, fenolik, karoten, dan fitoalbumin. Hal ini diperkuat oleh penelitian Rista (2018) bahwa rerata aroma yang panelis sukai yaitu biskuit yang ditambahkan tepung kulit buah naga merah $40 \%$ dengan skor 4,15 (sedap). Hal ini dikarenakan kepekaan panelis dengan tingkat kesukaan dan kepekaan yang menilai berbeda.

Tepung kedelai yang ditambahkan semakin banyak juga mempengaruhi aroma dari biskuit semakin kurang sedap. Hal ini karena kedelai mengandung senyawa volatil yang menyebabkan aroma langu pada kedelai. Hal ini sesuai dengan Lestari (2018) bahwa cookies yang berbasis tepung kedelai dan tepung ganyong (25:55) memiliki nilai aroma 3,44 (agak tidak sedap).

Tekstur

Berdasarkan hasil analisis ragam membuktikan bahwa formulasi biskuit dengan perbandingan tepung terigu, tepung kedelai dan tepung kulit buah naga merah berpengaruh terhadap organoleptik tekstur biskuit. Perolehan data organoleptik tekstur ditampilkan dalam Tabel 6. 
Tabel 6 Rerata Organoleptik Tekstur Produk Biskuit Formulasi Tepung Terigu, Kedelai, dan Kulit Buah Naga Merah

\begin{tabular}{cc}
\hline Formulasi Tepung & Hedonik Tekstur \\
Terigu(\%): Kedelai(\%): Kulit Buah Naga Merah(\%) & $3,40^{\mathrm{a}}$ \\
P0 $(100: 0: 0)$ & $3,35^{\mathrm{a}}$ \\
P1 $(80: 10: 10)$ & $3,40^{\mathrm{a}}$ \\
P2 $(70: 20: 10)$ & $3,90^{\mathrm{b}}$ \\
P3 $(60: 30: 10)$ & $4,35^{\mathrm{cd}}$ \\
P4 $(75: 10: 15)$ & $4,25^{\mathrm{c}}$ \\
P5 $(65: 20: 15)$ & $4,55^{\mathrm{e}}$ \\
P6 $(55: 30: 15)$ & $4,65^{\mathrm{e}}$ \\
P7 $(70: 10: 20)$ & $4,50^{\mathrm{de}}$ \\
P8 $(60: 20: 20)$ & $5,25^{\mathrm{f}}$ \\
\hline
\end{tabular}

Keterangan: Notasi yang ditulis dengan huruf berbeda menunjukkan ada perbedaan antar perlakuan berbeda nyata pada uji Duncan (DMRT) $5 \%$.

Keterangan skor: (1) sangat tidak keras, (2) tidak keras, (3) agak tidak keras, (4) netral, (5) agak keras, (6) keras, (7) sangat keras

Berdasarkan Tabel 6 diketahui bahwa rerata hedonik tekstur yang diperoleh dari penilaian panelis berkisar 3,35-5,25. Rerata tekstur biskuit yang disukai panelis semakin menurun seiring dengan tepung kedelai yang ditambahkan. Hal ini karena penambahan tepung kedelai menyebabkan tekstur biskuit menjadi lebih keras. Kerasnya tekstur disebabkan kadar protein yang tinggi pada tepung kedelai. Menurut Sabir (2020) protein bersifat hidrofilik. Protein yang terkandung dalam bahan menyebabkan kandungan air dalam bahan sukar dilepas ketika melewati proses pemanasan sehingga protein yang semakin tinggi dapat menurunkan kadar air. Hasil penelitian ini diperkuat dengan pernyataan Lestari (2018) yaitu cookies berbasis tepung ganyong dan tepung kacang kedelai menghasilkan tingkat kerenyahan sebesar 3,65-3,95 (agak renyah - renyah).

Tepung kulit buah naga merah yang ditambahkan juga mempengaruhi tekstur biskuit semakin keras. Tekstur yang paling keras menurut panelis adalah biskuit dengan proporsi tepung terigu 50\% : tepung kedelai $30 \%$ : tepung kulit buah naga merah $20 \%$ dengan rerata skor 5,25 (agak keras). Bahan pangan yang mengandung serat tinggi membuat teksturnya menjadi tidak renyah atau keras. Hal ini disebabkan bahan pangan yang berserat mengandung air yang sukar untuk menguap sehingga serat larut air didalamnya sulit teruapkan yang menyebabkan biskuit menjadi semakin keras. Hal ini sesuai dengan Saneto (2012) bahwa kulit buah naga merah mengandung serat pangan sebesar 46,7\%. Penelitian lain dari Triwulandari (2018) cookies berbasis tepung ampas tahu $20 \%$ dan tepung kulit buah naga merah $4 \%$ menghasilkan rerata skor dari panelis dengan nilai 2,40 (tidak renyah atau agak keras). 
Formulasi biskuit yang paling disukai disukai panelis adalah perlakuan dengan proporsi terigu 80\% : tepung kedelai 10\%: tepung kulit buah naga merah 10\% sebesar 3,35 karena tingkat kerenyahan yang sesuai. Hal ini karena penambahan tepung terigu yang paling dominan mengandung gluten cukup tinggi sehingga dapat menurunkan daya patah biskuit yang menyebabkan tekstur biskuit menjadi lebih renyah.

\section{Perlakuan Terbaik}

Perlakuan terbaik diperoleh dari pengujian data melalui metode de Garmo dengan menentukan bobot nilai berkisar 0-1 berdasarkan parameter yang lebih utama untuk dianalisis (Nafi, 2018). Penentuan tersebut dilaksanakan menurut parameter yang telah dianalisa yaitu kadar air, abu, protein, serat, lemak, dan organoleptik (rasa, aroma, dan tekstur). Hasil dari uji perlakuan terbaik ditampilkan dalam Tabel 7.

Tabel 7. Hasil Uji Perlakuan Terbaik Metode De Garmo pada Biskuit Formulasi Tepung Terigu, Kedelai, dan Kulit Buah Naga Merah

\begin{tabular}{ccc}
\hline Formulasi Tepung & Jumlah & Ranking \\
\hline Perigu(\%): Kedelai(\%): Kulit Buah Naga Merah(\%) & 0,546 & 6 \\
P1 $(100: 0: 0)$ & 0,615 & 2 \\
P2 $(70: 20: 10)$ & 0,596 & 3 \\
P3 $(60: 30: 10)$ & 0,663 & 1 \\
P4 $(75: 10: 15)$ & 0,525 & 7 \\
P5 $(65: 20: 15)$ & 0,595 & 4 \\
P6 $(55: 30: 15)$ & 0,556 & 5 \\
P7 $(70: 10: 20)$ & 0,364 & 9 \\
P8 $(60: 20: 20)$ & 0,316 & 10 \\
P9 $(50: 30: 20)$ & 0,509 & 8 \\
\hline
\end{tabular}

Berdasarkan Tabel 7 diketahui bahwa biskuit dengan perlakuan terbaik adalah perlakuan P3 (tepung terigu 60\%: tepung kedelai 30\%: tepung kulit buah naga merah 20\%) dengan kadar air 6,58\%, kadar abu 0,76\%, kadar protein 9,74\%, kadar lemak 27,95\%, dan kadar serat kasar 6,10\%, skor hedonik pada organoleptik rasa 4,65 (enak), aroma 4,95 (agak sedap), dan tekstur 3,90 (agak tidak keras). Hasil tersebut menunjukkan bahwa formulasi tersebut lebih disukai panelis karena rasa dari formulasi biskuit tersebut dapat diterima oleh panelis.

\section{KESIMPULAN}

Formulasi biskuit berbasis tepung terigu, tepung kedelai, dan tepung kulit buah naga merah mempengaruhi kadar air, protein, serat kasar, dan organoleptik (rasa, aroma, dan tekstur), kecuali kadar abu dan kadar lemak biskuit. Biskuit dengan proporsi tepung terigu 60\% : tepung kedelai 30\% : tepung 
kulit buah naga merah 10\% menghasilkan karakteristik dengan mutu yang mendekati SNI biskuit dengan kadar air 6,58\%, kadar abu 0,76\%, kadar protein $9,74 \%$, kadar lemak 27,95\%, kadar serat 6,10\%, skor hedonik pada organoleptik rasa 4,65 (enak), aroma 4,95 (agak sedap), dan tekstur 3,90 (agak tidak keras).

\section{REFERENSI}

Aini, N. Q., dan Y. Wirawani. 2013. Kontribusi MP-ASI Biskuit Substitusi Tepung Garut, Kedelai, dan Ubi Jalar Kuning Terhadap Kecukupan Protein, Vitamin A, Kalsium, dan Zink pada Bayi. Journal of Nutrition College. Vol 2(4).458-466. https://doi.org/10.14710/jnc.v2i4.3727

Balitkabi. 2016. Deskripsi Varietas Unggul Kacang-kacangan dan Umbi-umbian. Balai Penelitian Tanaman Kacang-kacangan dan Umbi-umbian. Malang.

BSN. 2011. SNI 2973-2011. Syarat Mutu Biskuit. Badan Standardisasi Nasional. Jakarta.

Cahyani, W., Rosiana, N.M. 2020. Kajian Pembuatan Snack Bar Tepung Gembili (Dioscorea Esculenta) Dan Tepung Kedelai (Glycine Max) Sebagai Makanan Selingan Tinggi Serat. Jurnal Kesehatan Polije. Vol 8(1). 1-9. https://doi.org/10.25047/j-kes.v8i1

Fajiarningsih, H. 2013. Pengaruh Penggunaan Komposit Tepung Kentang (Solanum tuberosum L.) Terhadap Kualitas Cookies. Food Science and Culinary Education Journal. Vol 2(1). 36-44. https://doi.org/10.15294/fsce.v2i1.2310

Jannah, N.W. 2020. Karakteristik Fisikokimia dan Organoleptik Cookies dengan Subtitusi Tepung Kulit Ari Kedelai (Glicine max L.) dan Penambahan Bubuk Kayu Manis. Disertasi. Universitas Muhammadiyah Malang. Malang.

Lestari, T.I., Nurhidajah, M. Yusuf. 2018. Kadar Protein, Tekstur, Dan Sifat Organoleptik Cookies yang Disubstitusi Tepung Ganyong (Canna edulis) dan Tepung Kacang Kedelai (Glycine max L.). Jurnal Pangan dan Gizi. Vol 8(6):53-63. https://doi.org/10.26714/jpg.8.1.2018.53-63

Lianawati, H.T.W., dan H. Warsito. 2019. Pembuatan Pancake Subtitusi Tepung Kulit Buah Naga Merah sebagai Makanan Selingan Sumber Antioksidan dan Serat bagi Penderita Diabetes Mellitus Tipe 2. Seminar Nasional INAHCO. Jember.

Nafi, A., Maqdiz, C.H.P. \& Maryanto, M. 2018. Karakterisasi Selai Oles Koro Pedang (Canavalia ensiformis L.) dengan Variasi Penambahan Susu Full Krim. Jurnal Agroteknologi. Vol 12 (2). 126-137. https://doi.org/10.19184/jagt.v12i02.9278 
Noor, M.I., E. Yufita, Zulfalina. 2016. Identifikasi Kandungan Ekstrak Kulit Buah Naga Merah Menggunakan Fourier Transform Infrared (FTIR) dan Fitokimia. Journal of Aceh Physics Society. Vol 5(1). 14-16.

Rista, E., Marianah, Y. Sulastri. 2018. Sifat Kimia dan Organoleptik Biskuit pada Berbagai Penambahan Ekstrak Kulit Buah Naga Merah. Jurnal Agrotek Vol 5(2). 127-133. https://doi.org/10.31764/agrotek.v5i2.704

Rochmawati, N. 2019. Pemanfaatan Kulit Buah Naga Merah (Hylocereus polyrhizus) sebagai Tepung untuk Pembuatan Cookies. Jurnal Pangan dan Agroindustri. Vol 7(3). 19-24. http://dx.doi.org/10.21776/ub.jpa.2019.007.03.3

Saneto, B. 2012. Karakterisasi Kulit Buah Naga Merah (Hylocereus polyrhizus). Jurnal Agarika. Vol 2(2). 143-149. https://doi.org/10.24961/j.tek.ind.pert.2020.30.2.228

Simangunsong, D. R. 2014. Kajian Kandungan Zat Makanan dan Pigmen Antosianin Tiga Jenis Kulit Buah Naga (Hylocereus sp.) Sebagai Bahan Pakan Ternak. Disertasi. Universitas Brawijaya. Malang.

Thomas, E. B., E. J. N. Nurali, T. D. J. Tuju. 2017. Pengaruh Penambahan Tepung Kedelai (Glycine max L.) Pada Pembuatan Biskuit Bebas Gluten Bebas Kasein Berbahan Baku Tepung Pisang Goroho (Musa acuminate L.). Journal Unsrat. Vol 1(7). 1-16.

Triwulandari, D., A. Mustofa, M. Karyantina. 2018. Karakteristik Fisikokimia dan Uji Organoleptik Cookies Kulit Buah Naga (Hylocereus undatus) dengan Substitusi Tepung Ampas Tahu. Jurnal Teknologi dan Industri Pangan. Vol 2(1). 61-66. http://dx.doi.org/10.33061/jitipari.v2i1.1537

Utama,I.D.G.D.A,N.W.Wisaniyasa,I.W.R.Widarta. 2019. Pengaruh Perbandingan Terigu dengan Tepung Kecambah Jagung (Zea mays L.) Terhadap Karakteristik Flakes. Jurnal Ilmu dan Teknologi Pangan Vol 8(2). 140-149. https://doi.org/10.24843/itepa.2019.v08.i02.p04

Yudiono, K. 2020. Peningkatan Daya Saing Kedelai Lokal Terhadap Kedelai Impor Sebagai Bahan Baku Tempe Melalui Pemetaan Fisiko-Kimia. Jurnal Agrointek. Vol 14(1). 57-66. https://doi.org/10.21107/agrointek.v14il.6311

Wu, L. C., Hsu, H. W., Chen, Y., Chiu, C. C., and Ho, Y. I. 2006. Antioxidant and Antiproliferative Activities of Red Pitaya. Food Chemistry. Vol 95(1). 31932. https://doi.org/10.1016/j.foodchem.2005.01.002 